\title{
PEMBAGIAN FACE SHIELD SEBAGAI PENCEGAHAN CORONA
}

\author{
Anna Pradiningsih ${ }^{1)}$, Baiq Leny Nopitasari'1), Alvi Kusuma Wardani1 ${ }^{1)}$, Baiq Nurbaety²), \\ Abdul Rahman Wahid²) \\ 1) S1 Farmasi, Fakultas IImu Kesehatan, Universitas Muhammadiyah Mataram, Kota Mataram, NTB, Indonesia \\ 2) D3 Farmasi, Fakultas IImu Kesehatan, Universitas Muhammadiyah Mataram, Kota Mataram, NTB, Indonesia
}

Corresponding author: Anna Pradiningsih

E-mail : annapradiningsih@gmail.com

\section{Diterima 17 September 2020, Direvisi 05 November 2020, Disetujui 05 November 2020}

\begin{abstract}
ABSTRAK
Keterbatasan APD (Alat Pelindung Diri) semakin memprihatinkan, sehingga perlunya pemasokan APD pada fasilitas kesehatan guna untuk mencegah pemaparan peyebaran covid-19 pada tenaga kesehatan. Dengan adanya kelangkaan alat pelindung diri, alternatif lain dalam perlindungan diri minimal untuk mencegah penyebaran Covid-19 ini adalah dengan menggunakan Face shield. Tenaga kesehatan di fasilitas kesehatan yang secara langsung memberikan pelayanan masyarakat memiliki resiko tinggi terkena penyebaran covid-19. Oleh karena itu, perlunya melakukan kegiatan dalam membantu penyediaan APD di fasilitas kesahatan salah satu nya adalah Face shield. Tujuan dari pengabdian masyarakat ini untuk membantu tenaga kesehatan dalam pencegahan penyebaran covid-19. Pada pengabdian masyarakat ini pembagian face shield dilakukan pada sejumlah puskesmas dan klinik antara lain Puskesmas Labuapi, Puskesmas Banyumulek, Puskesmas Perampuan dan Klinik An Nur. Metode pelaksanaan dilakukan secara langsung dengan jumlah total 50 buah face shield.
\end{abstract}

Kata kunci: face shield; pencegahan covid-19; Universitas Muhammadiyah Mataram

\begin{abstract}
The limitation of PPE (Personal Protective Equipment) is increasingly alarming, so the need for PPE supply in health facilities in order to prevent exposure to covid-19 distribution to health workers. Due to the scarcity of personal protective equipment, another alternative to minimal self-protection to prevent the spread of Covid-19 is to use a Face Shield. Health workers in health facilities that directly provide community services have a high risk of contracting co-19. Therefore, the need to carry out activities to help provide PPE in health facilities, one of which is Face Shield. The purpose of this community service is to help health workers in preventing the spread of covid-19. In this community service, the division of face shields was carried out in a number of puskesmas and clinics including Labuapi Puskesmas, Banyumulek Puskesmas, Perampu Puskesmas and An Nur Clinic. The method of implementation is carried out directly with a total of 50 face shields.
\end{abstract}

Keywords: face shield; Covid-19 prevention; University of Muhammadiyah Mataram

\section{PENDAHULUAN}

Cadangan APD global terutama masker medis, respirator, persediaan jubah, kacamata dan pelindung wajah saat ini tidak cukup untuk memenuhi kebutuhan global. Lonjakan permintaan global yang didorong tidak hanya oleh jumlah kasus Covid-19 melainkan juga oleh misinformasi, pembelian karena panik, dan penimbunan mengakibatkan semakin beratnya kekurangan APD secara global. Kapasitas untuk meningkatkan produksi APD terbatas, dan permintaan akan respirator dan masker saat ini tidak dapat dipenuhi, terutama jika APD terus banyak digunakan secara tidak tepat. Dengan adanya kelangkaan alat pelindung diri, alternative lain dalam perlindungan diri minimal guna mencegah penyebaran Covid-19 ini adalah dengan menggunakan Face shield. Dengan adanya kelangkaan alat pelindung diri, alternatif lain dalam perlindungan diri minimal guna mencegah penyebaran Covid-19 ini adalah dengan menggunakan Face shield. Face Shiled merupakan pelindung wajah yang memiliki kegunaan dalam meilndungi mata dan wajah dari percikan cairan darah atau droplet. Umumnya terbuat dari plastic bening transparan sehingga masih memberikan visibilitas yang baik bagi pengguna. Frekuensi pemakaian face shield adalah sekali pakai atau dapat dipergunakan kembali setelah dilakukan desinfeksi atau dekontaminasi.

APD adalah kontrol yang paling terlihat digunakan untuk mencegah transmisi, 
namun harus digunakan bersamaan dengan kontrol administratif dan rekayasa. Pemilihan APD harus benar dan digunakan dengan cara yang aman; masalah keamanan sangat pentingketika APD diletakkan, dilepasatau didekontaminasi. Praktik tenaga kesehatan sangat penting dalam memenuhi standar kewaspadaan dengan langkah-langkah Pengendalian Infeksi. Perlatan tersebut dirancang agar melindungi tenaga kesehatan dalam penyebaran infeksi khususnya corona virus dan pengendalian wabah.

Hal ini tidak terkecuali pada Provinsi Nusa Tenggara Barat, khususnnya Kabupaten Lombok Barat. Untuk menghadapi wabah virus Covid-19 yang kian mewabah, Pemda Lombok Barat (Lobar) dalam hal ini Dinas Kesehatan (Dikes) dihadapkan berbagai kendala. Di antaranya, kekurangan tenaga medis khususnya dokter di puskesmas yang ada dan Alat Pelindung Diri (APD) tenaga medis sudah limit.

Kelurahan Labuapi merupakan salah satu daerah yang mengalami kelangkaan APD tersebut. Fasilitas kesehatan yang terdapat dalam lingkup kelurahan Labuapi ini antara lain puskesmas dan klinik kesehatan.

Berdasarkan pemaparan hal tersebut diatas maka dianggap perlunya dalam pemasokan APD salah satunya adalah face shield pada fasilitas kesehatan. Oleh karena itu, kami melakukan kegiatan Pengabdian Masyarakat dengan judul "Pembagian Face shield sebagai Pencegahan Corona" pada kecamatan Labu Api, Kabupaten Lombok Barat. Fasilitas kesehatan dalam hal ini adalah Puskesmas dan Klinik di Kabupaten Lombok Barat.

\section{METODE}

Metode pelaksanaan pengabdian masyarakat ini dengan pembagian face shield secara langsung pada fasilitas kesehatan di kebupaten Lombok barat oleh seluruh tim pengabdian masyarakat. Tim terdiri dari ketua, anggota, tenaga administrasi dan mahasiswa. Mitra pada kegiatan ini adalah Puskesmas Labupai, Puskesmas Banyumulek, Puskesmas Perampuan dan Klinik An-Nur. Pembagian Face shield di Puskesmas Labuapi dan Puskesmas Perampuan sebanyak 15 buah, untuk Puskesmas Banyumulek sebanyak 10 buah dan untuk Klinik An Nur sebanyak 5 buah. Sedangkan untuk tim pelaksana sejumlah 5 buah sehingga total face shield yang dibagikan sebanyak 50 buah. Hal ini didasarkan pada tingkat urgensi tingginya resiko paparan penyebaran covid-19 di wilayah puskesmas dan klinik tersebut. Langkah pelaksanaan kegiatan antara lain :

\section{Pra Kegiatan}

Persipan pemesanan face shiled dalam dilakukan satu bulan sebelum kegiatan berlangsung. Face shield dipesan dari produsen percetakan di Yogyakarta. Setelah face shield sudah tersedia, kemudian dilakukan pengepakan sesuai jumlah yang akan didistribusikan.

\section{Pelaksanaan Kegiatan}

Pada pelaksanaan kegiatan sebelum dilakukan pembagian face shiled, Mitra Kegiatan mengisi daftar hadir dan berita acara penyerahan. Setelah itu, pembagian face shield sesuai dengan Mitra Kegiatan yang dituju yaitu Puskesmas Labuapi dan Puskesmas Perampuan sebanyak 15 buah, untuk Puskesmas Banyumulek sebanyak 10 buah dan untuk Klinik An Nur sebanyak 5 buah. Sedangkan untuk tim pelaksana sejumlah 5 buah sehingga total face shield yang dibagikan sebanyak 50 buah.

\section{Pasca Kegiatan}

Pasca kegiatan selesai, Mitra Kegitan mengisikan Surat Pernyataan telah selesai dilakukan kegiatan dalam hal ini diwakilkan oleh Puskesmas Labuapi

\section{HASIL DAN PEMBAHASAN}

Mitra pada kegiatan pengabdian masyarakat ini adalah puksemas dan klinik di kabupaten Lombok barat. Saat ini keterbatasan APD (Alat Pelindung Diri) semakin memprihatinkan, sehingga perlunya pemasokan APD pada fasilitas kesehatan guna untuk pencegah pemaparan peyebaran virus corona pada tenaga kesehatan. Peraturan Menteri Kesehatan Republik Indonesia Nomor 74 Tahun 2016 Tentang Standar Pelayanan Kefarmasian di Puskesmas menyatakan bahwa Pusat Kesehatan Masyarakat yang selanjutnya disebut Puskesmas adalah unit pelaksana teknis dinas kesehatan kabupaten/kota yang tanggung jawab menyelenggarakan pembangunan kesehatan di suatu wilayah kerja (Permenkes No 74 Tahun 2016). Puskesmas menjadi fasilitas kesehatan tingkat pertama yang secara langsung memberikan pelayanan kepada pasien. Sehingga menjadi filter awal dalam pencegahan penyebaran covid-19 ini. Tingkat resiko bagi tenaga kesehatan dapat terjadi paparan covid-19 ini sangat tinggi, oleh karena itu sangat perlu menggunakan APD dengan lengkap dan sebaik mungkin.

Peraturan Menteri Kesehatan Republik Indonesia Nomor 74 Tahun 2016 Tentang Standar Pelayanan Kefarmasian di Puskesmas menyatakan bahwa Pusat Kesehatan Masyarakat yang selanjutnya disebut 
Puskesmas adalah unit pelaksana teknis dinas kesehatan kabupaten/kota yang tanggung jawab menyelenggarakan pembangunan kesehatan di suatu wilayah kerja (Peraturan Menteri kesehatan No. 74, 2016).

Puskesmas menjadi fasilitas kesehatan tingkat pertama yang secara langsung memberikan pelayanan kepada pasien. Sehingga menjadi filter awal dalam pencegahan penyebaran covid-19 ini. Tingkat resiko bagi tenaga kesehatan dapat terjadi paparan covid-19 ini sangat tinggi, oleh karena itu sangat perlu menggunakan APD dengan lengkap dan sebaik mungkin.

Peraturan Menteri Kesehatan Republik Indonesia Nomor 9 Tahun 2014 tentang Klinik menyatakan bahwa Klinik merupakan fasilitas pelayanan kesehatan yang menyelenggarakan pelayanan kesehatan perorangan yang menyediakan pelayanan medis dasar dan/ atau spesialistik. Sedangkan untuk tenaga kesehatan adalah setiap orang yang mengabdikan diri dalam bidang kesehatan serta memiliki pengetahuan dan/atau keterampilan melalui pendidikan di bidang kesehatan yang untuk jenis tertentu memerlukan kewenangan untuk melakukan upaya kesehatan (Peraturan Menteri Kesehatan No 9, 2014 ).

Klinik merupakan fasilitas kesehatan tingkat pertama. Klinik juga menjadi filter awal dalam pencegahan penyebaran covid-19 ini sehingga tenaga kesehatan yang bertugas memiliki resiko yang tinggi dalam terjadinya paparan covid-19 ini. Oleh karena itu, sangat perlu menggunakan APD secara lengkap dan baik. Pembagian Face shield di Puskesmas Labuapi dan Puskesmas Perampuan sebanyak 15 buah, untuk Puskesmas Banyumulek sebanyak 10 buah dan untuk Klinik An Nur sebanyak 5 buah. Sedangkan untuk tim pelaksana sejumlah 5 buah sehingga total face shield yang dibagikan sebanyak 50 buah. Hal ini didasarkan pada tingkat urgensi tingginya resiko paparan penyebaran covid-19 di wilayah puskesmas dan klinik tersebut.

Pada era pandemic covid-19 ini segala upaya dalam pencegahan penyebaran covid19 perlu dilkukan, salah satu kontribusi Mitra dalam upaya melakukan pencegahan penyebaran covid-19 ini adalah dengan cara tenaga kesehatan menggunakan APD (Alat Pelindung Diri) yang baik dan benar sehingga dapat mengurangi resiko penyebaran covid-19 saat melakukan pelayanan kesehatan di fasilitas kesehatan ini. Sedangkan untuk institusi, kontribusi yang dapat dilakukan mitra adalah dapat memberikan promosi dengan memberikan testimoni atau kesan terhadap pelaksanaan kegiatan pengabdian masyarakat ini.

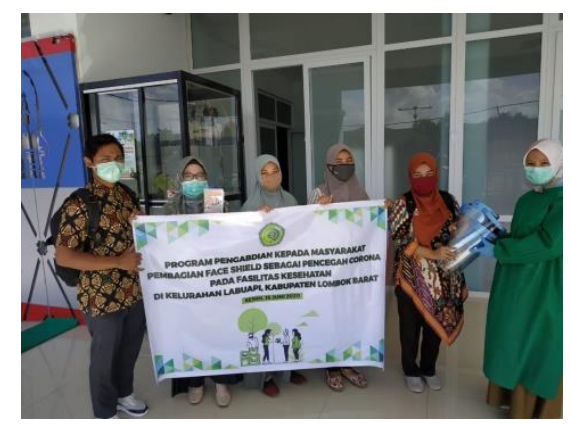

Gambar 1. Penyerahan Face shield pada Puskesmas Labuapi

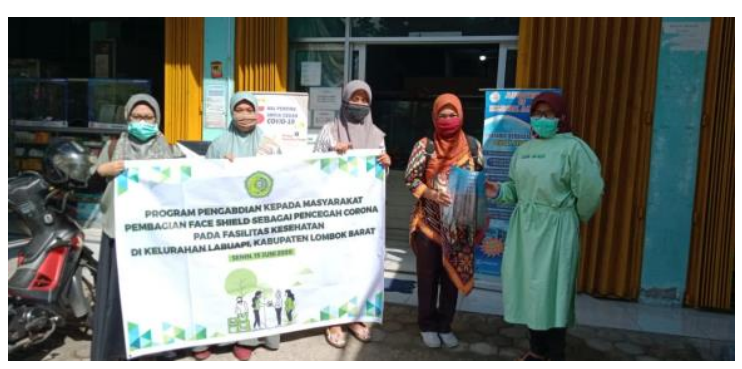

Gambar 2. Penyerahan Face shield pada Klinik An Nur

Pada pelaksanaan pembagian face shied ini secara langsung tim mendatangi puskesmas guna untuk menyerahkan bantuan APD berupa face shield. Pada kegiatan ini tim memotret beberapa permasalahan lain yang perlu untuk dikaji dan ditindak lanjuti lebih lanjut. Salah satunya adalah kurangnya kesadaran masyarakat dalam membantu melakukan pencegahan penyebaran covid-19. Fasilitas kesehatan sudah melakukan standar protocol kesehatan yaitu dengan menyiapkan tempat cuci tangan untuk dapat dipergunakan oleh masyarakat yang datang ke puskesmas tersebut. Tetapi tidak semua masyarakat yang melakukan protocol tersebut, beberapa orang melalaikan kegiatan cuci tangan dan langsung memasuki area puskesmas. Hal ini tentu tidak memungkinkan jika mengandalkan tenaga kesehatan di fasilitas kesehatan, tetapi harus memiliki kesadaran dari diri kita sendiri.

\section{SIMPULAN DAN SARAN Simpulan}

Kesimpulan kegiatan Pengabdian masyarakat dengan Judul "Pembagian Face shield sebagai Pencegah Corona" telah dilaksanakan dengan jumlah Face Shiled yang dibagikan sebanyak 50 buah. Dengan persebaran fasilitas kesehatan antara lain Puskesmas Labuapi, Puskesmas Banyumulek, Puskesmas Perampuan dan Klinik An Nur.

\section{Saran}

Saran yang dapat diberikan antara lain dapat memberikan bantuan APD (Alat 
Pelindung Diri) lainnya seperti masker, sarung tangan dan hazmat.

\section{UCAPAN TERIMAKASIH}

Puji syukur kehadirat Allah SWT yang telah melimpahkan Rahmat dan Karunia untuk kita semua sehingga Kegiatan Pengabdian Masyarakat dengan judul "Pembagian Face shield sebagai Pencegahan Corona pada Fasilitas Kesehatan" yang bertempat di Kecamatn Labuapi, Lombok Barat dapat terlaksana dengan baik. Atas kesempatan ini, penulis ingin mengucapkan terima kasih kepada Dekan Fakultas IImu Kesehatan, Universitas Muhammadiyah Mataram, Ibu Nurul Qiyaam M.Farm Klin., Apt., Kepala Puskesmas Labuapi, Kepala Puskesmas Banyumulek, Kepala Puskesmas Perampuan serta Kepala Klinik An Nur beserta staf dan jajarnnya..

\section{DAFTAR RUJUKAN}

Budi Nugroho, C., dan Pembuatan Faceshield, D., Syafei, M. G., Wiratno, S. S., Defta Rusdwinanto, C., Negeri Batam, P., Ahmad Yani, J., Tering, T., Kota, B., \& Batam, K. (2020). Desain dan Pembuatan Faceshield Sebagai Alat Perlindungan Diri Penyebaran Covid19. JURNAL PENGABDIAN MASYARAKAT (AbdiMas).

Peraturan Menteri Kesehatan No 9. (2014). Klinik. Jakarta: Republik Indonesia.

Peraturan Menteri kesehatan No. 742016 Tentang Pelayanan Kefarmasian di Puskesmas, (2016).

Respati, d. (2020). Kopidpedia. Bandung: Pusat Penerbitan Universitas (P2U) Unisba. 